\title{
An Empirical Study on Determinants of Business Performance of Korean Non-life Insurance Companies (Focused on ROA)
}

\author{
Sang Youl Kim ${ }^{1} \&$ Sang-Bum Park ${ }^{2}$ \\ ${ }^{1}$ Dept, of Business Administration, Graduate School of Korea Aerospace University, Korea \\ ${ }^{2}$ Professor, Korea Aerospace University, Korea \\ Correspondence: Sang-Bum Park, Professor, Korea Aerospace University, 76 Hanggongdaehang-ro, \\ Deogyang-gu, Goyang-city, Gyeonggi-do, 412-791, Korea. E-mail: psb@kau.ac.kr
}

Received: April 29, 2019

Accepted: September 19, 2019

Online Published: September 28, 2019

doi:10.5539/ijef.v11n10p118

URL: https://doi.org/10.5539/ijef.v11n10p118

\begin{abstract}
This study examines the total asset profitability, which is an indicator of business performance, using panel data for 10 years from 2005 to 2015 for 10 domestic insurance companies.

We analyze the factors affecting the ROA, compare the differences between before and after the enactment of the Capital Market Act, and assess the level of total assets of domestic insurance companies. Total Asset Margins As a result of analyzing the eight independent variables in order to identify the factors that affect the dependent variable, the factors affecting the total asset margins are (4) investment operating profit, insurance operating profit, business expense, appear. Among them, investment profits were the most influential factors. On the other hand, the factors affecting (-) the total asset profitability were analyzed as total capital, premium, leverage, and loss ratio. In particular, the total amount of capital has the largest negative impact on total assets. As a result of analyzing whether or not the total assets profit rate before and after enforcement of the Capital Market Act is the same, ROA, leverage, and period of operation were found to be the same before and after the Capital Market Act. On the other hand, insurance premiums, insurance operating profits, investment operating profits, business expenses, loss ratios, and total capital were analyzed before and after the implementation of the Capital Market Act. According to the results of the analysis of the total assets profit rate and the amount of the premium insurance, the second group has a $0.4 \%$ lower ROA than the first group but the third group is $41.8 \%$ lower than the first group. In other words, it can be seen that the ratio of total assets is lower than that of large companies.
\end{abstract}

Keywords: macroeconomics variables, non-life insurance, growth, ROA, determinants

\section{Introduction}

The insurance industry plays an important role in global or national economies. In the financial sector, the insurance sector accounts for a very large portion, and has a considerable impact on the stability of the financial market. Insurance companies' market activities provide the role of risk transfer and financial intermediation (Peter \& Kjell, 2008). The insurance industry, which provides financial services and risk transfer, is affecting both individuals and companies. Since the insurance company, which acts as a financial intermediary, currently has assets equivalent to 277 trillion and functions as a long-term investment institution for securities, loans and real estate, the continued growth of the insurance industry is essential for financial stability have.

Korea's non-life insurance is ranked 7th in the world. As of Dec. 2017, total asset of non-life insurance is 277.220 trillion won, premium is 78.6 trillion won, and net income is 3.9392 trillion won. In Korea, there are 32 domestic non-life insurers, including 14 domestic non-life insurers and 18 foreign non-life insurers. The number of employees working in 32 non-life insurance companies is 32,446 (monthly non-life insurance, 2015). 
Table 1. Key indicators of the Korean insurance market in the world insurance market

\begin{tabular}{ccccccccccc}
\hline \multirow{2}{*}{ Year } & \multicolumn{2}{c}{ Total } & \multicolumn{2}{c}{ Non-life Ins. } & \multicolumn{2}{c}{ Life Ins. } & \multicolumn{2}{c}{ Relative to GDP Premium ratio } & \multicolumn{2}{c}{ Per capita ins. Premium } \\
\cline { 2 - 11 } & Rank & $\%$ & Rank & $\%$ & Rank & $\%$ & Rank & $\%$ & Rank & US\$ \\
\hline 2013 & 8 & 3.13 & 9 & 2.67 & 8 & 3.50 & 5 & 11.9 & 20 & 2,895 \\
2014 & 8 & 3.34 & 9 & 2.73 & 8 & 3.83 & 4 & 11.3 & 19 & 3,163 \\
2015 & 8 & 3.37 & 9 & 2.74 & 7 & 3.88 & 6 & 11.4 & 18 & 3,034 \\
2016 & 7 & 3.61 & 7 & 3.15 & 7 & 3.98 & 5 & 12.1 & 18 & 3,362 \\
2017 & 7 & 3.70 & 7 & 3.51 & 7 & 3.87 & 5 & 11.6 & 14 & 3,522 \\
\hline
\end{tabular}

Data: Non-life Insurance Association Monthly Insurance report, 2017.

The return on equity (ROA) and return on equity (ROA), which are measured as a ratio of return on equity (ROE) and operating profit (operating income) Asset. There is controversy as to which of these two indicators is appropriate for the assessment of the non-life insurance company. In case of non-life insurance companies, it is more appropriate to use return on asset (ROA) as a representative profitability indicator that shows profitability. The reason for this is that insurance premiums imposed by customers are the source of financing and that the use of total assets, which is the sum of equity capital and liabilities, rather than equity capital, which is the share of shareholders in the denominator of the formula desirable. We can evaluate the performance of domestic non-life insurers by analyzing the total assets profit rate.

Korea's non-life insurers have become more important than any other competitors in the global market, in line with the growth of import premiums.

This study began to examine the level of total assets profitability that can assess the profitability of domestic non - life insurance companies in the world. And the purpose of the study is to find a solution to the following questions.

1) What are the decisive factors that affect the ROA of the domestic non-life insurance company, and what are the (+) and (-) factors?

2) The implementation of the Capital Market Consolidation Act in the domestic non-life insurer (February 2009) is expected to have a large impact on the non-life insurance companies. What is the change in the total asset profit before and after the enforcement of the Capital Market Consolidation Act?

3) What is the level of total assets of domestic non-life insurers, what should be improved to improve the total assets profit rate, and how should the non-life insurers' management strategies be set in the future?

Through this study, we will identify the cause of the above questions and find an optimal solution, and this will be an opportunity to establish a growth strategy for non-life insurance companies and secure global competitiveness.

\section{Literature Review}

\subsection{ROA}

Previous research on insurance company performance analysis focuses on profitability and financial soundness analysis.

Young-Mok (2008) used the return on equity (ROA), which measures the ratio of operating income to return on equity, as measured by the ratio of net profit to equity as an index of profitability of insurance companies. As a result of examining the ROA of non-life insurers until 1990-2006, they have been showing a decreasing trend since 2001, with cyclical pattern of repeated rise and fall. As of 2006, the total assets margin of the four major insurance companies is $1.9 \%$, and the total assets margin of small and medium-sized companies is $-1.5 \%$.

Joong-young (2003) conducted a survey of nine non-life insurance companies for the management evaluation of the non-life insurance companies. Based on the results of 1999-2001, A.M. Based on Best Credit Rating (Quantitative Evaluation) criteria, each management index segment and total score were calculated.

As a result of comparison with US leading insurers (AIG, Allstate, etc.), the management evaluation section shows 50.1 points for domestic insurers and 83.1 for advanced insurers in the US, which is a big difference in terms of growth potential, efficiency, profitability, safety and liquidity

In particular, when analyzed in terms of profitability (ROP) and return on assets (ROA), US leading insurers are achieving profits of $10.47 \%$ and $2 \%$, while domestic insurers are operating profit margin $(-0.88 \%)$ and total assets $1.42 \%$ ). 
These results show that the US non-life insurance industry is an industry that realizes the right balance, while the domestic non-life insurance industry is still a peeling business. In addition, the top insurance companies in Korea have taken a tendency to focus on quantitative growth, and advanced insurers in the US have pursued profit oriented management. Also, it can be seen that the domestic insurer groups are not aiming at quantitative and profit oriented management.

Gyu-ri, Jae-gyu, Kyung-hee, and Dong-gum (2007) proposed a model for analyzing the performance of insurance companies. The emphasis was on presenting direction. In the analysis of the insurance company management, the management performance analysis model is divided into the soundness - oriented management performance analysis model and the persistence - oriented management performance analysis model, and the analysis system and characteristics of these analysis models are analyzed systematically. And the analysis system, the overall performance of S \& P's insurance company valuation, a global insurance company rating agency, is reviewing the results of ROA. On the other hand, Moody's profitability assessment of non-life insurers uses ROE.

\subsection{Determinants of Corporate Performance and Profitability}

Hifza (2011) conducted descriptive statistics and multiple regression analysis of 35 life and non-life insurance companies listed in Pakistan to analyze the determinants that affect the profitability of insurance companies during 2005-2009 period. The average ROA of the 35 insurance companies in Pakistan was $0.1332 \%$, and the average business activity period was 23.6 years.

As a result of studying the effect of the duration of the business activity, the size of the company, the capital ratio, the leverage ratio and the loss ratio on the ROA, the duration of the company's business activities has nothing to do with profitability, While there is a positive impact on profitability, the loss ratio and leverage ratio have a negative impact.

Ana-Maria and Ghiorghe (2014) analyzed Rumania insurers' determinants of profitability through Panel data for the period 2008-2012. The determinants were six factors: financial leverage, size of the company, increase in premiums, underwriting risk, risk holdings, and solvency. Among them, the size of the company, the risk hold ratio, and the solvency capacity were evaluated as determinants that positively affect profitability.

Adams and Buckle (2010) analyzed panel data for the period 1993-1997, which determined the determinants of underwriting and investment-related firms' performance in the Bermuda insurance market.

As a result, companies with high leverage and low liquidity and reinsurance companies showed better operational performance than those with low leverage, high liquidity, and raw water insurance companies. Underwriting risk is positively related to performance, while firm size and scope are not important determinants.

Shiu (2004) conducted panel data analysis for the determinants of UK insurance company performance for the period 1986-1999. According to empirical results, this study shows that liquidity, unexpected inflation, interest rate level, and insurance operating profit are important factors in statistically determining UK insurance company performance.

In a study by Vigaykumar and Kadirvelu (2004), the duration of a firm's operating activities is an important determinant of profitability. The longer the company's business experience is, the higher the profitability is due to the operational experience and cost efficiency. They found that there was a positive relationship between the profitability of the firm and the duration of the firm's business activities.

According to Yang, Lianga, and Desheng (2008), the most commonly used ratios for evaluating business performance are the loss ratio and the cost ratio. The NYS Insurance Department has simplified the definition of loss ratio to the total premium rate paid for claims on certain types of long-term insurance. According to a study conducted in Thailand, the major factors affecting ROA for non-life insurance are capital stock, loss ratio and market dominance. And that the dominance of the market does not improve the profitability of the enterprise.

\section{Analysis Model and Data}

\subsection{Research Hypothesis}

In order to analyze the factors affecting the performance of an insurance company, it is necessary to establish an index that can represent the performance of the insurance. The performance of insurance companies is mainly analyzed in terms of profitability. The most commonly used index is ROA (return on asset). ROA is an index of net income divided by total assets, and is an indicator of how efficiently a particular financial institution has operated its total assets. In other words, it can be said that this is the most representative index of the management efficiency of financial institutions. The higher the indexes, the more efficient the management of 
insurance companies and the better the performance is.

Therefore, in this study, we try to analyze the performance of insurance companies using ROA as an indicator of the performance of insurance companies. Joong-young (2003) evaluated ROA and ROE in the management evaluation of the non-life insurance company as a measure of profitability. Profitability is the most important factor in insurer's operations and will be a key factor for insurers to continue to operate.

Operating profits, such as insurance profits and investment profits, are the most important source of surplus appreciation, and surplus is a safety device for contractors and companies, and has a significant impact on safety.

Young-Mok (2008) shows ROA in the analysis of profitability and financial soundness of non-life insurance companies as follows.

Total asset return $=$ Operating Profit $/$ Total Assets $=($ Owned Operating Profit $/$ Owned Premium + Investment Operating Profit / Owned Premium) * Owned Premium / Total Assets

$=($ Sales income insurance OPM + sales OPM $) \times$ total assets turnover

The purpose of the study is to identify the factors that affect the profitability of the non - life insurance company and to determine the relationship between the profitability of the insurance company and internal factors. Therefore, the following hypothesis is set and reviewed. The factors affecting ROA and management performance are different before and after the Capital Market Consolidation Act. The basic purpose of the Capital Market Consolidation Act is to promote restructuring of the financial industry, thereby promoting financial diversification and enlargement. Therefore, competition in the non-life insurance industry is becoming more intense than in the past, and it is not possible to survive without pursuing management rationalization.

\subsection{Research Method}

In this study, 10 domestic insurers (excluding overseas insurers and reinsurers) were selected and the panel data of insurance insurers' statistical data for 11 years from 2005 to 2015 were compared I want to use it.

The panel model means analyzing panel data in the form of a combination of time series data and cross section data. Time series data refers to data in which specific data are recorded in chronological order, and cross-sectional data refers to data that collects phenomena or characteristics at a specific point in time. In other words, the time series data is a time series of specific data, and the cross section data is a record of several observed data at a specific time point. The combination of the characteristics of the time series data and the cross section data is called the panel data, and the panel data has both the characteristics of the time series data and the cross section data. The multiple regression model of the panel model for analyzing the management performance is set as follows.

$$
Y i t=\propto+\beta X i t+\operatorname{eit}(i=1,2, \ldots m, t=1,2, \ldots . n)
$$

Here, the dependent variable $\mathrm{Y}$ represents the profitability of the company, and $\mathrm{X}$ represents the factors that affect profitability. $\mathrm{X}$ is composed of $\mathrm{k}$ vectors when the number of independent variables is $\mathrm{k}$. Subscript $\mathrm{i}$ denotes the number of cross sections for each insurance company, and t denotes the data coverage period for each cross section entity. The multiple regression model is based on the firm's ROA, ROA, sales underwriting, underwriting profit, investment profit, net business cost, loss ratio, Leverage, and period of business activity. Data will be analyzed with one dependent variable and eight dependent variables, profitability.

\subsection{Research Model}

To verify the hypothesis of this study, we use the model as shown in Figure 1.

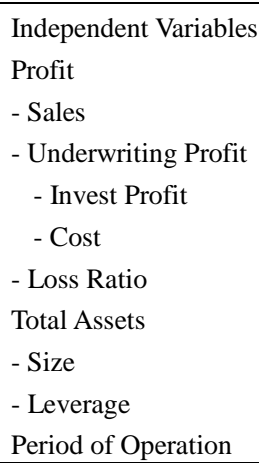

Figure 1. Research model 
This research model identifies which independent variables have an effect on the ROA and conducts hypothesis testing before and after the Capital Market Consolidation Act.

\subsection{Variable Definition}

The hypotheses and models included in this study are as follows. In general, the index used when evaluating the profitability of an insurance company is ROA (Return On Equity), which is measured by the ratio of net profit to equity, and ROA (Return On Asset), which is measured by the ratio of operating profit to total assets.

Because of the nature of the insurance company, it is desirable to use the combined total of equity and liabilities rather than equity capital, which is the share of shareholders in the denominator, since much of the funding is from the customer or company. Therefore, this study intends to use ROA as a dependent variable. Independent variables should select the factors that affect the ROA to obtain appropriate ROA results. Since ROA is the division of operating profit by total assets, the operating profit corresponding to the numerator was selected as five items that affect the net profit, namely, premium insurance, insurance operating profit, investment operating profit, net operating expense and loss ratio. The total amount of capital and leverage (total amount of liabilities / total amount of capital) representing the corresponding total assets were selected. In addition, a total of eight insurance companies were selected by adding the duration of business activity as an independent variable, considering that the duration of the insurance company's business activities would contribute to the interests of the insurance company.

In general, insurance companies earn investment profits through investment rather than insurance profits from insurance operations, and most insurance companies do not have a deficit. Details of variable names and variables are as follows.

Table 2. Variable name and variable description

\begin{tabular}{lll}
\hline Variable Name & & Description \\
\hline $\begin{array}{l}\text { Dependent Variable } \\
\text { Independent Var. }\end{array}$ & ROA(Return on Assets) & Net income/Total Asset \\
& Sales(Gross Premium) & The gross premium on the income statement \\
& Underwriting & $\begin{array}{l}\text { Profit excluding losses incurred from the premium received and net operating } \\
\text { expenses }\end{array}$ \\
& Income from reparation and investment \\
& Cost & Salary and general administrative expenses, \\
& New contract fee, agency fee \\
& Loss(Loss ratio) & Percentage of damages incurred divided by \\
& Progress insurance premiums \\
& Capital on B/S, retained earnings \\
& Total Debt/Capital \\
Period(Operating period) & Business activity period \\
\hline
\end{tabular}

Note. The data is from the KPSA statistical data.

\section{Empirical Analysis}

\subsection{Analysis of Basic Data for Each Variable}

In Korea, a total of 30 companies are operating, including domestic non-life insurance companies, overseas insurance companies, and reinsurance companies. In this study, we used 10 panel data of Korea National Insurance Association's insurance statistics for 11 years from 2005 to 2015, and it is found that it affects one dependent asset, ROA. The basic statistical data that analyzed 9 variables including 8 independent variables are as follows.

Table 3. Basic data statistics by variables

\begin{tabular}{|c|c|c|c|c|c|}
\hline Variable & Average & & Std. Deviation & Min. & Max. \\
\hline \multirow{3}{*}{ ROA } & overall & & 1.54 & -6.90 & 3.60 \\
\hline & between & 0.56 & 0.93 & -1.19 & 1.76 \\
\hline & within & & 1.23 & -5.57 & 5.35 \\
\hline \multirow{4}{*}{ Sales } & overall & & 37.03 & 2.70 & 1.78 \\
\hline & between & 40.04 & 30.74 & 5.75 & 1.04 \\
\hline & within & & 21.87 & -9.62 & 114 \\
\hline & overall & & 1.36 & -6.10 & 0.40 \\
\hline
\end{tabular}




\begin{tabular}{|c|c|c|c|c|c|}
\hline \multirow[t]{3}{*}{ Underwriting } & between & -1.33 & 0.67 & -2.66 & -0.65 \\
\hline & within & & 1.20 & -5.04 & 1.34 \\
\hline & overall & & 3.29 & -0.20 & 16.8 \\
\hline \multirow[t]{3}{*}{ Invest } & between & 3.01 & 2.71 & 0.39 & 9.41 \\
\hline & within & & 1.97 & -2.31 & 10.39 \\
\hline & overall & & 6.34 & 0.60 & 31.90 \\
\hline \multirow[t]{3}{*}{ Cost } & between & 7.22 & 5.50 & 1.17 & 18.8 \\
\hline & within & & 3.42 & -1.88 & 20.32 \\
\hline & overall & & 7.42 & 3.50 & 50.40 \\
\hline \multirow[t]{3}{*}{ Loss } & between & 31.73 & 9.02 & 4.83 & 34.63 \\
\hline & within & & 4.76 & 11.23 & 50.47 \\
\hline & overall & & 19.89 & 0.10 & 99.70 \\
\hline \multirow[t]{3}{*}{ Size } & between & 12.82 & 17.55 & 0.89 & 59.74 \\
\hline & within & & 10.04 & -17.51 & 52.89 \\
\hline & overall & & 18.27 & -20.20 & 187.7 \\
\hline \multirow[t]{3}{*}{ Leverage } & between & 12.45 & 5.43 & 4.85 & 24.22 \\
\hline & within & & 17.50 & -31.97 & 175.93 \\
\hline & overall & & 16.70 & 1.00 & 94.00 \\
\hline \multirow[t]{2}{*}{ Period } & between & 59.56 & 22.20 & 2.50 & 89.00 \\
\hline & within & & 3.12 & 54.58 & 64.58 \\
\hline
\end{tabular}

Note. Observation : N 103, n 10, T-bar 10.3.

When we look at basic data statistics by variables, the average ROA is 0.56 . The maximum of the data is 3.60 and the minimum is -6.90 , which shows the wide gap. Domestic non-life insurance companies earn KRW 4 trillion in sales and earn KRW 7 trillion in premiums from KRW1.8 trillion in 2005 and KRW 7 trillion in premiums. And underwriting profit has an average of -133 billion won in losses, while invest profit shows an average of 301 billion won. In other words, the insurance companies making an average of W170bn in operating profit due to invest profit from premiums charged to customers, although it is a deficit in underwriting, which is the main business of a non-life insurance company.

Non-life insurers' business cost averages KRW722.0bn, which is relatively high, while loss ratio is $31.7 \%$. The total amount of capital is an average of KRW1.2 trillion and the leverage that represents the ratio of debt to equity is 12.5 times. The average duration of the business operation is about 60 years which can make the accumulation of know-how on non-life insurance business.

\subsection{Verification of the Hypothesis}

The current Capital Market Integration Act was enacted on February 4, 2009, and the original name of the Act was the "Capital Market and Financial Investment Business Act", or the Capital Market Act. The Capital Market Act is a law enacted by incorporating six laws related to capital markets, including the Securities and Exchange Act, the Futures Trading Act, the Indirect Investment Asset Management Act, the Trust Business Act, the Comprehensive Financial Corporation Act, and the Korea Securities Futures Exchange Act. The basic purpose of the Capital Market Act is to promote financial innovation and fair competition in the capital market, as well as to nurture the financial investment industry by protecting investors. In addition, by accelerating the restructuring of the financial industry and promoting financial diversification and enlargement, competition in the non-life insurance industry is becoming more intense than in the past.

The ANOVA analysis was conducted to examine how the Capital Market Integration Act affects the return on assets (ROA) before and after the implementation of the Capital Market Act which is causing large changes in the financial environment. In general, ANOVA analysis has a disadvantage in that it can only judge whether the average value of each group is equal to each other. Therefore, the Bonferroni option is used to analyze the average of each group in more details
H0: $\mu 1 \neq \mu 2$
$\mathrm{H} 1: \mu 1=\mu 2$ 
Table 4. ANOVA analysis results

\begin{tabular}{lcccc}
\hline Variable & t-test statistic & p-value & \multicolumn{2}{c}{ ANOVA SS } \\
\cline { 3 - 5 } & & & between & within \\
\hline ROA & -0.25 & 0.43 & 1.48 & 239.33 \\
Sales & 26.89 & 0.00 & 16937.29 & 122893.37 \\
Underwriting & -1.09 & 0.000 & 27.57 & 161.67 \\
Invest & 2.07 & 0.00 & 100.11 & 1000.61 \\
Cost & 4.01 & 0.00 & 368.40 & 3665.50 \\
Loss & -5.00 & 0.00 & 586.03 & 5023.72 \\
Size & 10.31 & 0.11 & 2488.56 & 37857.24 \\
Leverage & 3.45 & 0.36 & 278.95 & 33759.57 \\
Period & 1.83 & 0.59 & 78.85 & 28346.20 \\
\hline
\end{tabular}

The result of testing the variance analysis of the hypothesis shows ROA, leverage, and periods of operation were found to be the same before and after the Capital Market Act. On the other hand, the sales of the premiums, underwriting, invest, cost, loss and size of capital were different, before and after the enactment of the Capital Market Act. Of these, the trends of the sales (insurance premiums), Underwriting(underwriting profit), invest (investment profit), Cost (business expenses), and Size (total capital) have been rising steadily over time, but the underwriting and the loss (loss ratio) have been on a downward trend. Therefore, we adopt a null hypothesis that all variables are not identical and therefore different before and after the enforcement of the Capital Market Integration Act.

\subsection{Regression Analysis}

The significance level of ROA is as follows.

Table 5. Results of analysis by model and by significance level of Return On Asset

\begin{tabular}{lccc}
\hline Model Case & Case I & Case II & Case III \\
\hline $\mathrm{R}^{2}$ & 0.48 & 0.46 & 0.15 \\
Sales & $-0.0024(-0.87)$ & - & 0.15 \\
Underwriting & $0.987 * * *$ & $0.916 * * *(6.05)$ & - \\
Invest & $1.210 * * *(4.28)$ & $0.949 * * *(6.46)$ & - \\
Cost & $0.053(0.33)$ & - & $0.325 *(1.75)$ \\
Loss & $-0.031(-1.65)$ & - & $-0.001(-0.03)$ \\
Size & $-0.102 * * *(-4.74)$ & $-0.090 * * *(-4.55)$ & - \\
Leverage & $-0.023 * * *(-3.47)$ & $-0.023 * * *(-3.49)$ & - \\
Period & $0.003(0.36)$ & - & $-0.013(-1.31)$ \\
Constant & $1.182 * *(1.99)$ & $0.364 *(1.831)$ & $0.655(0.51)$ \\
\hline
\end{tabular}

Note. $* \mathrm{p}<0.1, * * \mathrm{p}<0.05, * * \mathrm{p}<0.01$ (Statistically significant at $10 \%, 5 \%, 1 \%$ significance level), parentheses are $\mathrm{t}$ values.

As a result of analysis by model, $\mathrm{R}^{2}$, the determination coefficient of case 1 was 0.48 , which is the highest, the lowest is 0.15 of case 3 , and case 2 is 0.46 . The significance level for each variable is shown in the table. Panel data refers to time-series data in which a phenomenon or characteristic of a particular entity is recorded in time sequence, which is different from the cross-sectional data observed at a specific point in time. Thus, panel data has more information and variable volatility than cross-sectional or time series data. Panel data is sometimes missing due to the difficulty of the collection process, which leads to inefficiency of the estimator and a problem in identifying the parameter to be estimated.

The panel data needs to be separated into two error terms by their characteristics. There is an error term ' $\mu \mathrm{i}$ ', which has persistent characteristics that do not change with time in a single panel entity, and a pure anti-error term 'eit' that varies with the panel entity and time, although it exhibits heterogeneity that varies depending on the panel entity. The primary criterion for determining either a fixed effect model or a probability (random) effect model is the inference for $\mu \mathrm{i}$, which means the characteristics of the panel entity in the data. The Hausman test can be used to test the choice of the estimation model. The null hypothesis and the alternative hypothesis for the Houseman test can be used as follows.

$\mathrm{H} 0: \operatorname{COV}(\mathrm{Xit}, \mathrm{Ui})=0, \mathrm{H} 1: \operatorname{COV}(\mathrm{Xit}, \mathrm{Ui}) \neq 0$ If more efficient and the null hypothesis is wrong, that is, under H1, choose a fixed effect model that can yield a coincident estimator. 
The results of the regression analysis are as follows.

Table 6. Hausman test results of Return On Assets (ROA)

\begin{tabular}{lccccc}
\hline Variable Name & $\begin{array}{c}\text { Estimation of Fixed Effects } \\
\text { Model(b) }\end{array}$ & $\begin{array}{c}\text { Estimation of Random Effects } \\
\text { Model(B) }\end{array}$ & b-B & Squared S.E. & p-value \\
\hline Sales & 0.0070 & -0.0236 & 0.0306 & 0.0154 & 0.0307 \\
Underwriting & 0.8321 & 0.9872 & -0.1461 & 0.0693 & 0.037 \\
Invest & 1.4309 & 1.2097 & 0.2211 & 0.1043 & 0.037 \\
Cost & -0.2564 & 0.0530 & -0.3090 & 0.1125 & 0.037 \\
Loss & -0.0837 & -0.0307 & -0.0530 & 0.0176 & 0.037 \\
Size & -0.0190 & -1.024 & -0.0066 & 0.0199 & 0.037 \\
Leverage & -0.0161 & 0.0226 & 0.0045 & - & 0.037 \\
Period & -0.1387 & 0.0030 & -0.1366 & 0.0673 & 0.037 \\
\hline
\end{tabular}

According to the results in Table 6 , the p-value is 0.0307 , which is greater than 0.01 , so the null hypothesis is adopted at the $1 \%$ significance level. Thus, we can see that the random effects model is more efficient. The random effect model was also analyzed as follows according to the results of the house only test.

Table 7. Random effect analysis of Return On Assets (ROA)

\begin{tabular}{lccccc}
\hline Variable Name & Estimation (Coefficient) & Beta Value & \multicolumn{2}{c}{$\mathrm{R}^{2}$} & $\theta$ \\
\cline { 3 - 5 } & & & Overall & Between & Within \\
\hline Sales & -0.00236 & -0.5680 & & & \\
Underwriting & 0.9782 & 0.8672 & & & \\
Invest & 1.2098 & 2.5864 & & & 0.3090 \\
Cost & 0.0526 & 0.2160 & 0.4788 & 0.8227 & \\
Loss & -0.0310 & -0.1483 & & & \\
Size & -0.1025 & -1.3265 & & & \\
Leverage & -0.2260 & -0.2683 & & & \\
Period & 0.0030 & 0.0325 & & & \\
\hline
\end{tabular}

$\mathrm{R}^{2}$ is 0.4774 according to the result of random effects analysis, which seems to explain fully the dependent variable, ROA. Since the $\theta$ value is 0 and the assumption of $\operatorname{COV}$ (Xit, ui) $=0$ is established, the estimator of the random effect model is considered to be more efficient than the fixed effect estimator.

And Underwriting (underwriting profit), Invest (investment profit), and Cost (cost of business operations), and Period (period of business operation) have a positive effect on ROA, while Sales, loss (loss ratio), Size (Capital size), and Leverage (debt divided by capital) show (-) effect. In general, regression analysis shows that the effect of each variable is not the same per unit. Therefore, by estimating all the variables of the independent variable and the dependent variable by standardization, it is possible to solve the problem arising from the difference of measurement units between variables. In order to obtain the standardized estimation coefficients, beta option 4) was added to reevaluate the effect of independent variables on ROA.

The independent variables that affect the ROA are the order of investment operating profit (2.5864), insurance operating profit $(0.8672)$, business expense $(0.2160)$, and operating period $(0.0325)$. For example, when the investment operating profit increases by one unit, the total asset profit rate increases to 2.5864 times, which is the most influential independent variable. On the other hand, the independent variables affecting the ROA are the order of capital total (-1.3265), the premium on insurance premium (-0.5680), leverage $(0.2683)$, and the loss ratio $(-0.1483) 1$ unit increase, the total assets profit ratio seems to decrease by -1.3265 times.

\subsection{Dummy Analysis}

We use the dummy variable to further analyze the effect on ROA. 
Table 8. Analysis of Dummy's Effects on ROA

\begin{tabular}{|c|c|c|c|c|c|}
\hline Dummy Variable & & Case I & Case II & Case III & Case IV \\
\hline $\mathrm{R}^{2}$ & & 0.089 & 0.1041 & 0.0732 & 0.0096 \\
\hline \multirow[t]{2}{*}{ Sales } & group2 & -0.0039 & & & \\
\hline & group3 & -0.4176 & & & \\
\hline \multirow[t]{2}{*}{ Invest } & group2 & & -0.0750 & & \\
\hline & Group3 & & -0.6327 & & \\
\hline \multirow[t]{2}{*}{ Size } & group2 & & & -0.2707 & \\
\hline & group3 & & & -0.6505 & \\
\hline \multirow[t]{2}{*}{ Year } & group2 & & & & -0.1568 \\
\hline & Group3 & & & & -0.3917 \\
\hline
\end{tabular}

Note. Case I: Applying dummy variables to sales (group classification based on average of 4 trillion won or more in raw water insurance premium), group 1 (over 7 trillion won), group 2 (over 4 trillion won), group 3 (under 4 trillion won), and group 3 (under 4 trillion won).

Case II: Applying three dummy variables to investment operating profit (invest) (on average, 300 billion won or more), group 1 (in excess of 1 trillion won), group 2 (in excess of 300 billion won or less), group 3 (in excess of 300 billion won) and group).

Case III: Applying three dummy variables to the total size of capital (group classification based on average of 130 billion won or more), group 1 (4 trillion won or more), group 2 (4 trillion won less than 130 billion won), and group 3 (less than 130 billion won)

Case IV: Three groups of dummy variables are applied in the year, Group 1 (2005-2008), Group 2 (2009-2012), and Group 3 (2013-2015).

The results of applying the dummy variable show that ROA is lower in group 2 and group 3 than in group 1 when the other conditions are the same. Invest in the second group were lower by $6.75 \%$ than those in the first group and lower by $63.3 \%$ in the third group than in the first group. In the case of Size, group 2 and group 3 have showed a lower ROA ratio by $27.1 \%$ and $61.1 \%$ than group 1 , respectively.

In conclusion, the ROA premiums, investment operating profits, and total capital are lower in total assets. As a result of applying the dummy variables by dividing into three groups by year, the total asset profitability ratio was lower by $15.7 \%$ and $39.2 \%$ compared to $2005-2008$, when the two groups in the period of 2009-2012 and 2013-2015, As time goes by, the trend of ROA is gradually declining.

\section{Conclusion and Implications}

As of 2015, Korean non-life insurers accounted for KRW87.4 trillion in sales, ranking 7th in the world. However, they have not been able to realize proper amount of profit, in spite of this scale and global market position. The purpose of this study is to analyze the factors affecting the ROA by analyzing the panel data for 10 years from 2005 to 2015, The purpose of this study is to examine whether there is any change in the non-life insurance market before and after the enactment of the Capital Market Act. The regression analysis based on 103 panel data was conducted and the conclusions and implications are as follows.

First, what are the factors that affect the return on assets (ROA)? We analyzed 8 independent variables in order to identify the factors that affect the dependent variable. As a result, the factors affecting the ROA have been found to be 4 factors such as, Invest (investment profit), Underwriting (operating profit), Cost (cost of business operation), and Period (operating period). Among them, Invest is the biggest factor, and when the Invest is increased by 1 unit, the ROA ratio is increased by 2.586 times. In fact, most of the domestic non-life insurance companies show profits in the Invest, while the Underwriting is mostly in deficit, so the review of the business competitiveness that can benefit from the insurance business itself.

On the other hand, the factors affecting (-) the total asset profitability were the total of capital, premium on direct premium, leverage, and loss ratio. In particular, the total amount of capital has the largest negative impact on total assets. In the calculation of the total assets profit rate, the denominator is composed of capital and debt as the total assets, which means that it can not make profit according to the size of capital. When the total amount of capital is increased by one unit, the return on total assets is -1.3 times lower. The results of this study show that the relationship between leverage and loss ratio is the same, but the size of capital is different from the previous study.

Second, are the ROA before and after the Capital Market Act was in force? ROA, leverage, and period of operation were found to be the same before and after the Capital Market Act, according to the result of analyzing the data through the hypothesis test. On the other hand, the Sales (insurance premiums), Underwriting, Invest, Cost, Loss, and Size are different before and after the Capital Market Act. In order to analyze this in more detail, it is divided into three groups and analyzed by dummy variable. 
The results show that the ROAs of two groups, in 2009-2012 and 2013-2015 are lower by $15.7 \%$ and $39.2 \%$ than those of the 2005-2008 period which was before the implementation of the Capital Market Act. This shows that the trend of ROA is gradually falling with the passage of time, which is not a positive signal for the management of domestic non-life insurers. The results of previous studies show that the total assets profit ratio of non-life insurers has been declining since 2001, and the ROA ratio of major companies (the top four companies in market share) is $1.9 \%$ in 2006 and the ROA ratio of small and mid-sized companies is just -1.5\% Both large and small and medium-sized firms reported that their Underwriting profits were far low with their assets expanding.

Third how high are the ROAs of domestic non-life insurers? As of 2015, there are four companies with the Sales amount (premium volume) of at least KRW 7 trillion (Group 1), two companies in Group 2, with the sales between four and seven trillions, and four companies with less than four trillions (Group 3). According to the results of the analysis of the ROA and the Sales, the Group 2 has a ROA lower by $0.4 \%$ than the Group 1 but the third group is lower by $41.8 \%$ than the Group 1 . In other words, it can be seen that the ROA of small and medium sized insurers is lower than that of large companies.

Previous studies show, companies in the developed market or leading countries have realized a profit of $2 \%$ in terms of ROA, while the domestic companies have recorded a $-1.42 \%$ deficit. The top companies in the domestic market have realized $1.13 \%$ profit, but the companies ranked lower in the market did $-2.55 \%$. In this study, the data for 11 years from 2005 to 2015 shows that the ROA is 0.56 , min. -6.90 , and maximum 3.60 , so that the difference between the companies is very large and the ROA is lower than that of advanced companies in the developed countries. It can be seen that domestic non - life insurance companies have been negligent in focusing on making profits but on bringing up the premium volume.

We expect this study might contribute to improving the ROA of domestic non-life insurance companies based on the analysis of which factors are affecting the ROA and how big their influences are, as well as analysis of the trend of ROA in years. In addition, this study is short of identifying the differentiations and the factors to be improved, comparing and analyzing those globally leading insurers, which is caused by a lack of data that can be used to analyze the difficulty of securing data and the difference between domestic and advanced management. It is considered that there is a significant difference in return on asset (ROA) since each country has different management strategies. Thus, it is necessary to review in what areas the regional comparison and the company size are distinguished in the future study.

\section{References}

Adams, M., Hardwick, P., \& Zou, H. (2008). Reinsurance and corporate taxation in the United Kingdom life insurance industry. Journal of Banking \& Finance, 32(1), 101-115. https://doi.org/10.1016/j.jbankfin.2007.09.006

Ali, K., Akhtar, M. F., \& Ahmed, H. Z. (2011). Factors influencing the profitability of conventional banks of Pakistan. International Research Journal of Finance and Economics, 2(6), 235-242.

Almajali, A. Y., Alamro, S. A., \& Al-Soub, Y. Z. (2012). Factors affecting the financial performance of Jordanian insurance companies listed at Amman Stock Exchange. Journal of Management Research, 4(2), 266. https://doi.org/10.5296/jmr.v4i2.1482

Al-Shami, H. A. A. (2008). Determinants of insurance companies' profitability in UAE. University Utara Malaysia.

Athanasoglou, P. P., Brissimis, S. N., \& Delis, M. D. (2008). Bank-specific, industry-specific and macroeconomic determinants of bank profitability. Journal of International Financial Markets, Institutions And Money, 18(2), 121-136. https://doi.org/10.1016/j.intfin.2006.07.001

Boadi, E. K., Antwi, S., \& Lartey, V. C. (2013). Determinants of profitability of insurance firms in Ghana. International Journal of Business and Social Research, 3(3), 43-50.

Born, P. H. (2001). Insurer profitability in different regulatory and legal environments. Journal of Regulatory Economics, 19(3), 211-237. https://doi.org/10.1023/A:1011161805740

Bourke, P. (1989).Concentration and other determinants of bank. Journal of Banking and Finance, 13(1), 65-79. https://doi.org/10.1016/0378-4266(89)90020-4

Burca, A. M., \& Batrinca, G. (2014). The determinants of financial performance in the Romanian insurance market. International Journal of Academic Research in Accounting. Finance and Management Sciences, 4(1), 299-308. https://doi.org/10.6007/JJARAFMS/v4-i1/637

Byoung-dae, C. (2002). Corporate insurance demand and corporate insurance strategy of non-life insurers. 
Insurance Finance Research, 34.

Chen, R., \& Wong, K. A. (2004). The determinants of bank insurance: Empirical validation in the Tunisian context. Journal of Risk and Insurance, 71(3), 469-499. https://doi.org/10.1111/j.0022-4367.2004.00099.x

Chen-Ying, L. (2014). The effects of firm specific factors and macroeconomics on profitability of property-liability insurance industry in Taiwan. Asian Economic and Financial Review, 4(5), 681.

Cho, Y. H., \& Lee, H. E. (2017). Comparison of Profitability of Major Insurance Companies. KIRI Weekly, 415.

Cristea, M., Marcu, N., \& Cârstina, S. (2014). The relationship between insurance and economic growth in Romania compared to the main results in Europe-A theoretical and empirical analysis. Procedia Economics and Finance, 8, 226-235. https://doi.org/10.1016/S2212-5671(14)00085-9

Eun-Hoe, P. (1991). Income elasticity of demand for insurance claims. Journal of Insurance, 37.

Greene, W. H., \& Segal, D. (2004). Profitability and efficiency in the US life insurance industry. Journal of Productivity Analysis, 21(3), 229-247. https://doi.org/10.1023/B:PROD.0000022092.70204.fa

Gun-sik, R., Chang, G., Kyung-hee, L., \& Dong-kyum, K. (2007). A comparative study on insurance company performance analysis model. Korea Institute of Public Finance Research Report, 11-194.

Hae-il, Y., \& Jae-bok, L. (2009), Management efficiency analysis of on-line non-life insurance company. Insurance Finance Research, 57.

Hailegebreal, D. (2016). Macroeconomic and firm specific determinants of profitability of insurance industry in Ethiopia. Global Journal of Management and Business Research, 16(7).

Haiss, P., \& Sümegi, K. (2008). The relationship between insurance and economic growth in Europe: A theoretical and empirical analysis. Empirica, 35(4), 405-431. https://doi.org/10.1007/s10663-008-9075-2

Hardwick, P., \& Adams, M. (2002). Firm size and growth in the United Kingdom life insurance. Journal of Risk and Insurance, 69(4), 577-593. https://doi.org/10.1111/1539-6975.00038

Hong-joo, J., Hee-soo, J., \& Mi-soo, C. (2000). An Empirical Study on the Relationship between Insurance, Savings, and GNP. Journal of the Insurance Society of Korea, 56.

Hyeyeon, L., Byun, H. W., \& In-young, J. (2012). Study on the Entrance and Exit of Insurance Industry. Policy Research Institute, 2012, 21-180.

Hye-yeon. (2002). A study on determinants of corporate insurance demand. Risk Management Research, 13(1).

Jeon, S. J., \& Yong-Sik, J. (2014). Analysis of the impact of the macroeconomic environment on the insurance industry. Korea Insurance Research Institute, 51-80.

Jong-hyeop, S., \& Dae-Kyo, S. (2009). Analysis of insurance demand determinants in advanced insurance countries including Korea. Insurance Financial Research, 58.

Jung, J. Y. (2003). Management evaluation and implications of domestic non-life insurers. Insurance Finance Research, 38 .

Kanwal, S., \& Nadeem, M. (2013). The impact of macroeconomic variables on the profitability of listed commercial banks in Pakistan. European Journal of Business and Social Sciences, 2(9), 186-201.

Kyoung-Ju, L., \& Ki-hyup, L. (1998). Statistical Analysis of Insurance Company Management Evaluation. Risk Management Study, 10(1).

Lai, G. C., \& Limpaphayom, P. (2003). Organizational structure and performance: Evidence from the non-life insurance industry in Japan. Journal of Risk and Insurance, 70(4), 735-757. https://doi.org/10.1046/j.0022-4367.2003.00073.x

Lim, D. B. (2008). Economic Effects of Interest Rate Fluctuations. Industrial Economics Research, 21(2),

Lim, T., \& Jeon, Y. S. (2017). The effect of macroeconomic risk on the insurance industry and its ripple effects, the behavior of contractors due to macroeconomic changes and insurance company risk management seminar. Applied Statistics Research, 21(5).

Malik, H. (2011). Determinants of insurance companies profitability: an analysis of insurance sector of Pakistan. Academic Research International, 1(3), 315.

Mayers, D., \& Smith Jr, C. W. (1988). Ownership structure across lines of property-casualty insurance Foundations of Insurance Economics (pp. 532-559). https://doi.org/10.1007/978-94-015-7957-5_26 
Outreville, J. F. (1990). The economic significance of insurance markets in developing countries. J Risk Insur, 57(3), 487-498. https://doi.org/10.2307/252844

Papaioannou, E. (2007). Finance and growth - a macroeconomic assessment of the evidence from a European angle. ECB working paper no. 787.

Pervan, M., \& Pavić, K. T. (2010). Determinants of insurance companies' profitability in Croatia. The Business Review Cambridge, 16(1), 231-238.

Rousseau, P. L., \& Wachtel, P. (1998). Financial intermediation and economic performance: Historical evidence from five industrialized countries. J Money, Credit, Banking, 30(4), 658-678. https://doi.org/10.2307/2601123

Sambasivam, Y., \& Ayele, A. G. (2013). A study of the performance of insurance companies in Ethiopia. International Journal of Marketing, Financial Service \& Management Research, 2(7), 138-150.

Sang-wook, N. (2006). Causal relationship between insurance industry and economic growth. Journal of Insurance, (74).

Sa-young, K., \& Yong-jae, S. (2015). A Study on the Impact of the Non-life Insurance Industry on the Korean Economy. Journal of the Insurance Society of Japan, 102. https://doi.org/10.17342/KIJ.2015.102.1

Seung-woo, H. (2011). A Study on the Status and Management Evaluation of Non-life Insurance Companies in Korea. Journal of Financial Management, 17(1), 39-53.

Shim, J. (2011). Mergers \& acquisitions, diversification and performance in the US property-liability insurance industry. Journal of Financial Services Research, 39(3), 119-144. https://doi.org/10.1007/s10693-010-0094-3

Su"megi, K., \& Haiss, P. (2008). The relationship between insurance and economic growth: Review and agenda. Icfai J Risk Insurance, 5(2), 32-56.

Suk-young, K., Se-joong, K., \& Hye-ran, K. (2014), Diagnosis and Improvement of Profit Structure of Insurance Companies. Korea Insurance Research Institute, 101-99.

Tae-hyuk, K., Chun-kwang, P., \& Byung-chul, K. (2008). Static and Dynamic Analysis on the Efficiency and Determinants of Domestic Insurance Companies. Financial Management Research, 25(4).

Ward, D., \& Zurbruegg, R. (2000). Does insurance promote economic growth-evidence from OECD countries. $J$ Risk Insur., 67(4), 489-506. https://doi.org/10.2307/253847

Yong-Sik, J., \& Young-Hyun, C. (2016). Changes in Management Environment and Strategies of Major Overseas Insurance Companies. Korea Insurance Research Institute, 11-105.

Zou, H., \& Adams, M. B. (2004). The corporate purchase of property insurance: Chinese evidence. J. Financ Intermed., 15(2), 165-196. https://doi.org/10.1016/j.jfi.2004.06.007

\section{Copyrights}

Copyright for this article is retained by the author(s), with first publication rights granted to the journal.

This is an open-access article distributed under the terms and conditions of the Creative Commons Attribution license (http://creativecommons.org/licenses/by/4.0/). 